\title{
Characterizing Microbial Populations in Petroleum-Contaminated Soils of Swat District, Pakistan
}

\author{
Muhammad Nazir Uddin', Murtaza Ali ${ }^{1}$, Muhammad², Muhammad Farooq $^{2}$, \\ Nisar Ahmad ${ }^{1}$, Johar Jamil'², Kalsoom², Muhammad Adnan³, \\ Nazish Shah ${ }^{4}$, Ahsan Khan ${ }^{4 *}$ \\ ${ }^{1}$ Center for Biotechnology and Microbiology, University of Swat, Pakistan \\ ${ }^{2}$ Department of Microbiology, University of Swabi, Pakistan \\ ${ }^{3}$ Department of Agriculture, University of Swabi, Pakistan \\ ${ }^{4}$ Department of Zoology, University of Swabi, Pakistan
}

Received: 3 December 2015

Accepted: 2 February 2016

\begin{abstract}
Soil samples from petroleum-contaminated soil were collected from 25 different petroleum filling stations and automobile workshops in the district of Swat, Khyber Pakhtunkhawa, Pakistan. A total of seven bacterial genera were isolated. All of the isolates were Gram-positive bacteria. The genera identified by the culture and cell morphological characteristics were: Bacillus, Streptococcus, Staphylococcus, Micrococcus, Corynebacterium Arthrobacter, and Streptomyces. Lipolytic and saline activities of the selected isolates were studied. Among the isolates, Arthrobacter, Staphylococcus, Bacillus, Micrococcus, Corynebacterium, and Streptomyces produced lipase enzymes, while no lipase was produced by Streptococcus. Dense growth of Bacillus and Streptococcus was observed at $1 \% \mathrm{NaCl}$. Dense growth of Streptomyces was observed at strength of $2 \% \mathrm{NaCl}$. At $3 \% \mathrm{NaCl}$ concentration, dense growth of Staphylococcus, Micrococcus, Corynebacterium, and Arthrobacter was observed, indicating that they were moderately halotolerent. In our study, Bacillus, Arthrobacter, and Streptomyces showed optimum growth at pH 8.0, and Streptococcus, Staphylococcus, and Micrococcus showed optimum growth at $\mathrm{pH}$ 7.0. Only Corynebacterium showed optimum growth at $\mathrm{pH} 9.0$, indicating that it is tolerant of higher $\mathrm{pH}$ conditions.
\end{abstract}

Keywords: Hydrocarbons, Bioremediation, Arthrobacter, Staphylococcus, Bacillus, Micrococcus, Corynebacterium, Streptomyces

*e-mail: Ahsanyousafzai27@yahoo.com 


\section{Introduction and Background}

Petroleum is widely used across the globe as a primary source of energy and fuel [1]. In 2003 its estimated consumption was about 13.1 billion liters per day and is increasing daily [2]. Hydrocarbons are the main constituent of petroleum and are the major cause of environmental pollution [3]. Hydrocarbons are biological in origin [4]. Land disposal of pollutants is the simplest and easiest method, although it may be re-exposed to the environment by landsliding or other activities. Similarly, burning of pollutants may produce carbon dioxide, which is a potential hazard to the environment in the forms of air pollution and global warming. Furthermore, both land disposal and incineration are time-consuming and not safe for living organisms [5].

Bioremediation is the process by which much environmental pollution (including petroleum products) is converted to less toxic or harmless substances by using microorganisms or their metabolic capabilities. The resulting products can be carbon dioxide, water, and other simpler compounds that do not affect the environment [6].

The rate of pollutant degradation is affected by several physical, chemical, and biological factors such as $\mathrm{pH}$, temperature, nutrients, water and oxygen availability, type of organism, and nature of pretreatment [7]. In soil environment the highest degradation rates generally occur in the range of $30-40^{\circ} \mathrm{C}$, while in some freshwater environments it is $20-30^{\circ} \mathrm{C}$ and in marine environments it is $15-20^{\circ} \mathrm{C}$ with a normal $\mathrm{pH}$ of 6-8 under aerobic conditions [8, 9] for isolated Pseudomonas, Staphylococcus, Micrococcus, Salmonella, Cellobiococcus, and Pneumonia from oil stations and auto mechanic workshops. These genera obtained optimal growth at different temperatures between $20^{\circ} \mathrm{C}$ and $90^{\circ} \mathrm{C}$ and at different $\mathrm{pH}$ levels, ranging from acidic to alkaline. Similarly, bacterial genera Pseudomonas and Rahnella showed a higher ability to degrade naphthalene at $4^{\circ} \mathrm{C}$ [10]. Micrococcus spp., Pseudomonas spp., and Bacillus spp. can degrade hydrocarbons at normal $\mathrm{pH}(68)$ and temperature $\left(25-40^{\circ} \mathrm{C}\right)$ under aerobic conditions [8].

Various types of bacteria such as Acinetobacter, Aeromonascaviae, Bacillus, Bravibacterium, Citrobacter, Citrobacterkoseri, Corynebacterium, Enterobacter, Erwinia, Eschericha, Gordonia, Klebsiella, Maltophilia Micrococcus, Micromonospora, Mycobacterium, Neisseria, Nocardia, Proteus, Pseudomons, Rhodococcus, Sphingobacterium, multivorum, Stenotrophomonas, and Streptococcus could degrade a high percentage of hydrocarbon pollution [11-14]. In fungi, i.e., Penicillin spp., Aspergillus spp., Rhizopus spp., Alternaria spp., and Cladosporium spp. could degrade petroleum hydrocarbons [7]. Individual microorganisms can degrade only a low quantity of hydrocarbon pollutants. Mixed culture of microbes can be used to increase the rate of hydrocarbon biodegradation [15]. It was observed that bacterial spp such as Lysini bacillus, Brevibacillus, Paenibacillus, Alcaligenes, Delftia, Achromobacter, and Brevibacteriu motitidis showed maximum hydrocarbon degradation rates in mixed culture [16].

In Pakistan, especially in the Swat region of Khyber Pakhtunkhwa, limited research has been available on the bioremediation of environmental pollution caused by petroleum products.

\section{Materials and Methods}

\section{Sample Collection}

For the current study, 25 samples from petroleumcontaminated soil were collected from 25 different locations of petroleum filling stations and automobile workshops around the Swat Valley from Bahrain to Barikot. The samples were collected in sterilized plastic bags and each bag was labeled to show the date and site of sample collection. The samples were then brought to the university laboratory for further processing.

\section{Media Preparation and Sterilization}

\section{Nutrient Agar Medium}

Nutrient agar media was prepared by adding $28 \mathrm{~g}$ of nutrient agar powder to $1000 \mathrm{ml}$ of distilled water. The constituents of nutrient agar media were peptone $5 \mathrm{~g} / \mathrm{L}$, meat extract $1 \mathrm{~g} / \mathrm{L}$, yeast extract $2 \mathrm{~g} / \mathrm{L}, \mathrm{NaCl} 5 \mathrm{~g} / \mathrm{L}$, and agar $15 \mathrm{~g} / \mathrm{L}$ with a $\mathrm{pH} 7.0$, supplemented with $1 \%$ $(1 \mathrm{~mL} / 100 \mathrm{~mL})$ cycloheximide. The solution was stirred using a magnetic stirrer to ensure the complete dissolution of the compounds. The media was sterilized in an autoclave for 15 minutes at 15 psi and was poured into $90 \mathrm{~mm}$ sterilized Petri dishes.

\section{Nutrient Broth Medium}

Nutrient broth medium was prepared by adding $13 \mathrm{~g}$ of nutrient broth powder to $1000 \mathrm{ml}$ of distilled water. The chemical constituent of nutrient broth was peptone $5 \mathrm{~g} / \mathrm{L}$, meat extract $1 \mathrm{~g} / \mathrm{L}$, yeast extract $2 \mathrm{~g} / \mathrm{L}$, and $\mathrm{NaCl} 5 \mathrm{~g} / \mathrm{L}$ with a $\mathrm{pH}$ 7.0. The solution was stirred using a magnetic stirrer to ensure that the compound was completely dissolved. The media was sterilized in an autoclave for 15 minutes at $15 \mathrm{psi}$ and was poured into $10 \mathrm{ml}$ sterilized test tubes.

\section{MacConky Agar Medium}

MacConky agar medium was prepared by adding 50 grams of MacConky agar to $1000 \mathrm{ml}$ of distilled water. Its chemical composition was peptone $17 \mathrm{~g} / \mathrm{L}$, protease peptone $3 \mathrm{~g} / \mathrm{L}$, lactose $10 \mathrm{~g} / \mathrm{L}$, bile salt $1.5 \mathrm{~g} / \mathrm{L}$, sodium chloride $5 \mathrm{~g} / \mathrm{L}$, neutral red $00.3 \mathrm{~g} / \mathrm{L}$, crystal violet $0.001 \mathrm{~g} / \mathrm{L}$, and agar $13.5 \mathrm{~g} / \mathrm{L}$ with neutral $\mathrm{pH}$ 7.0. The solution was stirred using a magnetic stirrer to ensure that the compound was completely dissolved. The media was sterilized in an autoclave for 15 minutes at $15 \mathrm{psi}$ and poured into $90 \mathrm{~mm}$ sterilized Petri dishes. 


\section{Effect of Temperature on the Growth of Isolates}

The growth rate of the isolates was checked at different temperature ranges from $20^{\circ} \mathrm{C}$ to $40^{\circ} \mathrm{C}$ for temperature optimization.

\section{Isolation of Bacteria}

Soil samples were serially diluted $\left(10^{-1}\right.$ to $\left.10^{-9}\right)$ and $10^{-6}$ tube samples were inoculated on the plates with the help of a wire loop and kept for $24-48$ hours at $37^{\circ} \mathrm{C}$ for the growth of bacterial colonies. Bacterial colonies were subsequently streaked three to four time on fresh plates of nutrient agar media for pure colonies isolation, then the fresh culture were kept at $37^{\circ} \mathrm{C}$ for $24-48$ hours and stored in the refrigerator at $4^{\circ} \mathrm{C}$ for future use.

\section{Identification of Bacteria}

The following tests and procedures were used to verify the identity of the screened and selected bacteria for hydrocarbon degradation.

\section{Morphological Characteristics}

Selected isolates were characterized by colony morphology on nutrient agar, Gram staining, and morphological characteristics like colony size, shape, structure, opacity, elevation, pigmentation, and margin as describe by Holt et. al (1994) for identification of the isolates [17].

\section{Gram Staining Procedure}

The Gram staining technique was used for differentiation between Gram positive and Gram negative bacteria. A drop of sterilized water was placed on a neat and clean glass slide, and a single isolated colony of 24-72 hours-old culture was mixed in it. The smear was made by spreading the culture. This smear was air dried and fixed by rapidly passing the slide three times over the flame and flooded with crystal violet for one minute and gently washed with distilled water, then Gram iodine was poured on the slide for another minute and gently washed with distilled water. The slide was drained by acetone for $10-20 \mathrm{sec}$ and gently washed with distilled water. Finally safranin was poured on the slide for one minute and it was gently washed with distilled water, after which the slides were kept under bibulous paper, air-dried, and examined under the oil immersion objective lens (100x) of a light microscope.

\section{Selective Media}

Gram-negative bacteria were inoculated on MacConky agar media for isolate confirmation and Gram-positive were inoculated on nutrient agar media.

\section{Growth Rate of Isolates at Different Salt Concentrations (Saline Activity)}

The isolates were grown at nutrient agar media (as mentioned earlier) supplemented with $1-3 \%(\mathrm{w} / \mathrm{v}) \mathrm{NaCl}$ for saline activity.

\section{Lipolytic Activity}

Selected isolates were grown at $1 \%(\mathrm{v} / \mathrm{v})$ Olive oil for the determination of lipolytic activity and lipase production. The bacterial colonies that produced a shallow zone around them were considered lipase positive, while those colonies with no shallow zone around them were considered lipase negative.

\section{Effect of $\mathrm{pH}$ on the Growth of Isolates}

The growth of isolates was checked at various $\mathrm{pH}$ levels (5-10). Diluted $\mathrm{HCl}$ was added drop by drop to the growth medium for acidic $\mathrm{pH}$, and basic $\mathrm{pH}$ was adjusted by adding $\mathrm{NAOH}$ to the medium.

\section{Results}

Isolation and Culture Morphological Characteristics of Petroleum Degraders

Among different sampling locations, various bacterial genera like Bacillus, Streptococcus, Staphylococcus, Micrococcus, and Corynebacterium Arthrobacter were isolated (Table 1). The isolated genera were identified on the basis of morphological characteristics such as colony shape, colony size, colony elevation, marginal outlines, colony opacity, surface, and pigmentation (Table 1).

Cell Morphological and Gram Staining Characteristics of Selected Bacterial Isolates

Cell morphological characteristics like cell size and shape on agar plates were studied and examined. Furthermore, the Gram staining tests were conducted several times for identification of the selected isolates (Tables 2, 3).

\section{Effect of Temperature on Isolate Growth}

The effect of Temperature on the growth of selected isolates was checked. Among the Micrococcus isolates, Arthrobacter and Corynebacterium showed low growth at $20^{\circ} \mathrm{C}$, moderate growth at $25^{\circ} \mathrm{C}$, and dense growth at 30-37 $7^{\circ}$. Similarly, Staphylococcus, Bacillus, Streptococcus, and Streptomyces also showed low growth at $20^{\circ} \mathrm{C}$, moderate growth at $25^{\circ} \mathrm{C}$, and dense growth at $30-37^{\circ} \mathrm{C}$. The most suitable temperature selected based on bacterial growth was $37^{\circ} \mathrm{C}$. This temperature $\left(35^{\circ} \mathrm{C}\right)$ was the incubation temperature employed for further investigation (Table 4). 
Table 1. Isolation of petroleum-degrading bacteria from different petroleum-contaminated soil sites.

\begin{tabular}{|c|c|c|}
\hline $\begin{array}{l}\text { Sample } \\
\text { No. }\end{array}$ & Name of sample location & Name of Isolates \\
\hline 1 & Bahrain petrol pump & Arthrobacter Bacillus \\
\hline 2 & Bahrain Workshop 1 & Bacillus \\
\hline 3 & Barikot Workshop 1 & $\begin{array}{c}\text { Bacillus, } \\
\text { Staphylococcus }\end{array}$ \\
\hline 4 & Barikot Workshop 3 & Staphylococcus \\
\hline 5 & Barikot Workshop 4 & Micrococcus \\
\hline 6 & Barikot Petrol Pump & Staphylococcus \\
\hline 7 & Charbagh Petrol Pump & Bacillus \\
\hline 8 & Fizagut Workshop & $\begin{array}{c}\text { Corynebacterium, } \\
\text { Arthrobacter }\end{array}$ \\
\hline 9 & Fizagut Petrol pump & Bacillus \\
\hline 10 & Khwazakhela Petrol pump & $\begin{array}{c}\text { Streptomyces, } \\
\text { Bacillus }\end{array}$ \\
\hline 11 & Khwazakhela Workshop 1 & Bacillus \\
\hline 12 & Khwazakhela Workshop 2 & Bacillus \\
\hline 13 & Manglawar Petrol Pump & Streptococcus \\
\hline 14 & Matta Petrol Pump & Staphylococcus \\
\hline 15 & Mingora Petrol Pump & Bacillus \\
\hline 16 & Mingora Workshop 1 & Arthrobacter \\
\hline 17 & Mingora Workshop 2 & Bacillus \\
\hline 18 & Odigram Petrol Pump & Bacillus \\
\hline 19 & Qamber Petrol Pump & Arthrobacter \\
\hline 20 & Rahim abad Petrol Pump & Streptococcus \\
\hline 21 & Rahim abad Workshop 1 & Bacillus \\
\hline 22 & Rahim abad Workshop 2 & Bacillus \\
\hline 23 & Satal Petrol Pump & Arthrobacter \\
\hline 24 & Watkay Workshop 1 & Bacillus \\
\hline 25 & Watkay Workshop 2 & $\begin{array}{c}\text { Bacillus, } \\
\text { Arthrobacter }\end{array}$ \\
\hline
\end{tabular}

\section{Lipolytic Activity of Selected Bacterial Isolates}

Lipase activity of selected isolates was studied. Among the Arthrobacter isolates, Staphylococcus, Bacillus, Micrococcus, Corynebacterium, and Streptomyces showed lipase activity by producing a shallow zone around their colonies, whereas Streptococcus did not produce a shallow zone around its colony hence it was lipase negative (Table 5).

\section{Effect of Different $\mathrm{NaCl}$ Concentrations on Growth of Selected Bacterial Isolates}

The growth of identified isolates was checked for saline activity on Nutrient agar medium enriched with $1 \%, 2 \%$, and $3 \% \mathrm{NaCl}(\mathrm{w} / \mathrm{v})$ concentrations. Bacillus and Streptococcus showed dense growth at $1 \% \mathrm{NaCl}$, moderate growth at $2 \% \mathrm{NaCl}$, and low growth at $3 \% \mathrm{NaCl}$. Staphylococcus, Micrococcus, Corynebacterium, and Arthrobacter showed low growth at $1 \% \mathrm{NaCl}$, moderate growth at $2 \% \mathrm{NaCl}$, and dense growth at $3 \% \mathrm{NaCl}$, while Streptomyces showed low growth at $1 \% \mathrm{NaCl}$, dense growth at $2 \% \mathrm{NaCl}$, and moderate growth at $3 \% \mathrm{NaCl}$ (Table 6).

\section{Effect of Different $\mathrm{pH}$ Ranges on the Growth of Isolates}

Data presented in Table 7 describe the effects of different $\mathrm{pH}$ ranges on the growth of selected isolates. Bacillus, Micrococcus, Corynebacterium, and Streptomyces spp showed no growth at $\mathrm{pH}$ 5.0, while the remaining isolates showed low growth at $\mathrm{pH}$ 5.0. All of the isolates showed low growth at $\mathrm{pH} 6.0$ except for Streptococcus, which showed normal growth at $\mathrm{pH}$ 6.0. Streptococcus, Staphylococcus, and Micrococcus showed optimum growth at pH 7.0; and Bacillus, Corynebacterium, and Arthrobacter showed normal growth at $\mathrm{pH} 7.0$; while only Streptomyces showed low growth at $\mathrm{pH}$ 7.0. Bacillus, Arthrobacter, and Streptomyces showed optimum growth at $\mathrm{pH} 8.0$, while the remaining isolates showed normal

Table 2. Morphological characteristics of selected bacterial isolates.

\begin{tabular}{|c|c|c|c|c|c|c|c|}
\hline Name of isolates & Shape & Size & Elevation & Margin & Opacity & Texture & Pigment \\
\hline Bacillus & Irregular & Large & Umbonate & Undulate & Opaque & Rough & White \\
\hline Streptococcus & Round & Large & Flat & Entire & Opaque & Smooth & Bright Yellow \\
\hline Staphylococcus & Round & Medium & Convex & Entire & Opaque & Smooth & Whitish \\
\hline Micrococcus & Round & Medium & Convex & Entire & Opaque & Smooth & Yellow \\
\hline Corynebacterim & Irregular & Medium & Convex & Entire & Transparent & Granular & Yellowish \\
\hline Arthrobacter & Round & Large & Convex & Entire & Opaque & Smooth & Light Yellow \\
\hline Streptomyces & Irregular & Medium & Raised & Entire & Opaque & Wrinkle & Light Brown \\
\hline
\end{tabular}


Table 3. Cell morphological and Gram staining characteristics of selected bacterial isolates.

\begin{tabular}{|c|c|c|c|}
\hline Name of isolate & Size & Shape & $\begin{array}{c}\text { Gram } \\
\text { staining }\end{array}$ \\
\hline Bacillus & Big & Rod & + \\
\hline Streptococcus & Small & Cocci & + \\
\hline Staphylococcus & Small & Cocci & + \\
\hline Micrococcus & Small & Cocci & + \\
\hline Corynebacterium & Big & Rod & + \\
\hline Arthrobacter & Small & Rod coccus & + \\
\hline Sterptomyces & Big & Filamentous rod & + \\
\hline
\end{tabular}

$+=$ Gram positive

Table 4. Effect of temperature on the growth of isolates.

\begin{tabular}{|c|c|c|c|}
\hline Name of isolate & $20^{\circ} \mathrm{C}$ & $25^{\circ} \mathrm{C}$ & $30-40^{\circ} \mathrm{C}$ \\
\hline Bacillus & + & ++ & +++ \\
\hline Streptococcus & + & ++ & +++ \\
\hline Staphylococcus & + & ++ & +++ \\
\hline Micrococcus & + & ++ & +++ \\
\hline Corynebacterium & + & ++ & +++ \\
\hline Arthrobacter & + & ++ & +++ \\
\hline Streptomyces & + & ++ & +++ \\
\hline
\end{tabular}

$+=$ Low growth; $++=$ Moderate growth;

$+++=$ Dense growth

Table 5. Lipolytic activity of selected bacterial isolates.

\begin{tabular}{|c|c|}
\hline Name of isolate & Lipolyticactivity \\
\hline Bacillus & + \\
\hline Streptococcus & - \\
\hline Staphylococcus & + \\
\hline Micrococcus & + \\
\hline Corynebacterium & + \\
\hline Arthrobacter & + \\
\hline Streptomyces & + \\
\hline
\end{tabular}

$+=$ Lipase production and $-=$ No Lipase production.

growth at pH 8.0. Only Corynebacterium showed optimum growth at pH 9.0, while Micrococcus, Arthrobacter, and Streptomyces showed normal growth at $\mathrm{pH} 9.0$ and the remaining isolates showed low growth at $\mathrm{pH}$. Similarly, Streptococcus, Staphylococcus, and Micrococcus showed no growth at $\mathrm{pH} 10.0$ and the remaining showed low growth at $\mathrm{pH} 10.0$.
Table 6. Effect of different $\mathrm{NaCl}$ concentrations on the growth of selected bacterial isolates.

\begin{tabular}{|c|c|c|c|}
\hline Name of isolate & $1 \% \mathrm{NaCl}$ & $2 \% \mathrm{NaCl}$ & $3 \% \mathrm{NaCl}$ \\
\hline Bacillus & +++ & ++ & + \\
\hline Streptococcus & +++ & ++ & + \\
\hline Staphylococcus & + & ++ & +++ \\
\hline Micrococcus & + & ++ & +++ \\
\hline Corynebacterium & + & ++ & +++ \\
\hline Arthrobacter & + & ++ & +++ \\
\hline Streptomyces & + & +++ & ++ \\
\hline
\end{tabular}

$+=$ low growth; $++=$ Moderate growth; $+++=$ Dense growth .

Table 7. Effect of different $\mathrm{pH}$ ranges on the growth of isolates.

\begin{tabular}{|c|c|c|c|c|c|c|}
\hline Name of Isolate & $\mathrm{pH}$ & $\mathrm{pH}$ & $\mathrm{pH}$ & $\mathrm{pH}$ & $\mathrm{pH}$ & $\mathrm{pH}$ \\
& 5.0 & 6.0 & 7.0 & 8.0 & 9.0 & 10.0 \\
\hline Bacillus & - & + & ++ & +++ & + & + \\
\hline Streptococcus & + & ++ & +++ & ++ & + & - \\
\hline Staphylococcus & + & + & +++ & ++ & + & - \\
\hline Micrococcus & - & + & +++ & ++ & ++ & - \\
\hline Corynebacterium & - & + & ++ & ++ & +++ & + \\
\hline Arthrobacter & + & + & ++ & +++ & ++ & + \\
\hline Streptomyces & - & + & + & +++ & ++ & + \\
\hline
\end{tabular}

$+=$ Low growth, $++=$ Normal growth,

$+++=$ Optimum growth, $-=$ No growth

\section{Discussion}

Microorganisms like bacteria are important biodegrading agents of petroleum hydrocarbons. Various types of bacteria have been reported that have promising abilities of degradation [18-19]. They break down the complex hydrocarbon chain and utilize their carbon energy sources. There are various external factors like temperature, humidity, oxygen, nutrients, and water availability that can influence their biodegrading ability [20]. The present study confirms various bacterial associations with petroleum hydrocarbons taken from soil samples of different regions of the Swat District in Khyber Pakhtunkhawa.

In the present study, seven differentbacterial genera (i.e., Bacillus, Streptococcus, Staphylococcus, Micrococcus, Corynebacterium, Arthrobacter, and Streptomyces) were isolated from various petroleum-contaminated soils. Our study is in line with Raza et al., (2011), who isolated Micrococcusspp., Corynebacteriumspp., and Bacillusspp from crude oil-contaminated soil [11]. Similar results have been reported by other researchers [9, 21-22], who reported that Streptococcus spp., Arthrobacter spp, 
Staphylococcus spp., Micrococcus spp, and Bacillus sp can grow and degrade crude oil.

Various cultural and morphological characteristics of bacteria have been studied by various researchers [23]. In the present study, colony shape, colony size, colony elevation, marginal outlines, and colony opacity, surface, and pigmentation were studied and observed in different genera. Similar reports have been obtained by Ahirwar and Dehariya (2013) and Mhamane et al. (2013) [13, 24]. In the present study the effect of temperature on the growth of bacteria was also studied, which revealed variations in growth and morphological traits. Similar reports have been reported by Sunita et al. (2013) and Rehab et al. (2013) $[25,26]$.

In our study enriched media with $1 \%(\mathrm{v} / \mathrm{v})$ olive oil was used for lipase activity of the identified isolates. The results indicated that Arthrobacter, Staphylococcus, Bacillus, Micrococcus, Corynebacterium, and Streptomyces were lipase-positive, while negative lipase activity was found in streptococcus. Our results are in agreement with [27, 28]; Mohan et al., 2008 and Vishnupriya et al., (2010), who reported a potent lipase-producing bacteria, Streptomyces griseus (a bacillus species), by using different types of oils, including olive, palm, and sunflower. Nisha et al. (2014) also isolated Micrococcus flavus and recorded its lipase production at $27^{\circ} \mathrm{C}$ to $37^{\circ} \mathrm{C}$ [29].

In our study Bacillus, Arthrobacter, and Streptomyces showed optimum growth at $\mathrm{pH} 8.0$, and Streptococcus, Staphylococcus, and Micrococcus showed optimum growth at $\mathrm{pH}$ 7.0. Only Corynebacterium showed optimum growth at $\mathrm{pH}$ 9.0. Our results are in line with the findings of Olajuyigbe and Nisha [30-31], who reported that Bacillus spp and Micrococcus spp can grow and produce protease and cellulose enzyme at $\mathrm{pH} 8.0$ and 7.0, respectively.

\section{Conclusions}

Lots of microorganisms adapt to petroleumcontaminated soil. During this research 25 soil samples were collected from petroleum filling stations and automobile workshops in the Swat District of Khyber Pakhtunkhwa, Pakistan. A total of seven bacterial genera - all Gram-positive - were isolated. These genera were Streptococcus, Bacillus, Micrococcus, Staphylococcus, Arthrobacter, Streptomyces, and Corynebacterium. During our research it was found that most of the microorganisms showed optimum growth in saline environments, indicating that they tolerate high $\mathrm{pH}$ conditions.

\section{References}

1. OKOH A.I. Biodegradation of Bony light crude oil in soil microcosm by some bacterial strains isolated from crude oil flow station saver pits in Nigeria. African Biotech, 2 (5), 104, 2003.

2. Energy Information Administration (EIA). (2006). Annual Energy Review. http://www.eia.gov/kids/energy. cfm?page=about_home-basics.
3. SEBIOMO A., BANKOLE S.A., AWOSANYA A.O. Determination of the ability of microorganisms isolated from mechanic soil to utilise lubricating oil as carbon source. African Journal of Microbiology Research, 4 (21), 2257, 2010.

4. SURRIDGE A.K.J. Denaturing gradient gel electrophoresis characterisation of microbial communities in polycyclic aromatic hydrocarbon and polychlorinated biphenyl contaminated soil. PhD Thesis. University of Pretoria, South Africa, 1, 2007.

5. SHARMA S. Bioremediation: Features, Strategies and applications. Asian Journal of Pharmacy and Life Science, 2 (2), 202, 2012.

6. DAS K., MUKARJEE A.K. Crude petroleum oil degradation efficiency of Bacillus Subtitles and Pseudomonas aerations strains isolated from a petroleum oil contaminated soil from North-East India. Bioresearch Technology, 98 (7), 1339, 2011.

7. SANTHINI K., MYLA J., SAJANI S., USHARANI G. Screening of micrococcus spp from oil contaminated soil with refrence to bioremediation. Botany Research International, 2 (4), 248, 2009.

8. PARAMANIK D., RAJALAKSHMI G. Biodegredation of petroleum hydrocarbons pollutants in soil using microbial consortium. International Journal of Plant, Animal and Environmental Sciences, 3 (3), 173, 2013.

9. BADRUNNISA S., SHANTARAM M., PAI R.V. Isolation, Characterization and Identification of bacteria from coolant oils. International Journal of Applied Biology and Pharmaceutical Technology. 2 (3), 444, 2011.

10. MA Y., WANG L., SHAO Z. Pseudomonas, the dominant polycyclic aromatic hydrocarbon-degrading bacteria isolated from Antarctic soils and the role of large plasmids inhorizontal gene transfer. Environmental Microbiology, 8 (3), 455, 2006.

11. RAZA C., LIAQAT S., BASHIR S., NASEER M., ISHRAT N. Characterization of crude oil contaminated soil bacteria and laboratory-scale biodegradation experiments. Biologia (Pakistan), 57 (1, 2), 47, 2011.

12. ERDOGAN E.E., SAHIN F. KARACA A. Determination of petroleum degrading bacteria isolated from crude oil contaminated soil in Turkey. African Journal of Biotechnology, 10 (20), 166, 2011.

13. MHAMANE P., SHAIKH N., SOHANI H.M. RAJASHREE Isolation and Characterization of Hydrocarbon Degrading Bacteria's isolated from Diesel Polluted Soil from Various Petrol-Diesel Bunk of Solapur. International Journal of Recent Trends in Science And Technology, 9 (2), 178, 2013.

14. IDEMUDIA M.I., NOSAGIE A.O., OMOREDE O. Comparative assessment of degradation potentials of bacteria and actinomycetes in soil contaminated with motorcycle spent oil. Asian Journal of Science and Technology, 5 (8), 482, 2014.

15. THENMOZHI R., NAGASTHYA A. THAJUDDIN N. Studies on bioremedation of used engine oil by consortium cultures. Advances in Environmental Biology, 5 (6), 1051, 2011.

16. DZULKAPLI N.F., TALIB S.A., RAMASAMY K., YANG Y.C. Identafication of bacterial strains capable of degrading malasian petroleum sludge. Conference on Scientific and Social Research, 8 (9), 55, 2009.

17. HOLT J.G., KRIEG N.R., SNEATH P.H.A., STALEY J.T., WILLIAMS S.T. Bergey's Manual of Determinative Bacteriology. $9^{\text {th }}$ Ed. Williams and Wilkins. Mpp: 71-561, 1994.

18. OBOH B.O., ILORI M.O., AKINYEMI J.O., ADEBUSOYE S.A. Hydrocarbon Degrading Potentials of Bacteria Isolated 
from a Nigerian Bitumen (Tarsand) Deposit. Nature and Science, 4 (3), 1, 2006.

19. ROY A.S, BARUAH R., BORAH M., SINGH A.K., BORUAH H.P.D., SAIKIA N., DEKA M., DUTTA N., BORA T.C. Bioremediation potential of native hydrocarbon degrading bacterial strains in crude oil contaminated soil under microcosm study. International Biodeterioration \& Biodegradation, 94, 79, 2014.

20. PANDA S.K., KAR R.N., PANDA C.R. Isolation and identification of petroleum hydrocarbon degrading microorganisms from oil contaminated environment. International Journal of Environmental Sciences, 3 (5), 1315, 2013.

21. JAYASHREE R., NITHYA S.E., PRASANNA P.R., KRISHNARAJU M. Biodegradation capability of bacterial species isolated from oil contaminated soil. J. Acad. Indus. Res, 1 (3), 140, 2012.

22. JABORO A.G., AKORTHA E.E., OBAYAGBONA O.N. Suspectibility to heavy metals and hydrocarb on clastic attributes of soil microbiota. International Journal of Agriculture Biosciences, 2 (5), 206, 2013.

23. SHUBHRASEKHAR C., SUPRIYA M., KARTHIK L., GAURAV K., BHASKARA RAO K.V. Isolation, characterization, and application of biosurfactant produced by marine action bacteria isolated from saltpan soil from costal area of Andhra Pradesh, India. Research Journal of Biotechnology, 8 (1), 18, 2013.

24. AHIRWAR S., DEHARIYA K. Isolation and characterization of hydrocarbon degrading microorganisms from petroleum oil contaminated soil sites.Bulletin of Environmental and Scientific Research, 2 (4), 5, 2013.
25. SUNITA V.J., DOLLY R.P., BATEJA S., VIVEK U.N. Isolation and Screening for Hydrocarbon Utilizing Bacteria (HUB)from Petroleum Samples. International Journal of Current Microbiology and Applied Sciences, 2 (4), 48, 2013.

26. REHAB S., RAMADHA REBAH N., JABBAR, ABDULATIF N. Isolation, Identification, and Assessment the ability of local Streptomyces isolate from Iraq to utilize crude oil and diesel fuel. Science Park Journals, 2 (1), 9, 2013.

27. MOHAN T.S., PALAVESAM A., IMMANVEL G. Isolation and characterization of lipase-producing Bacillus strains from oil mill waste. African Journal of Biotechnology, 7 (15), 2728, 2008

28. VISHNUPRIYA B., SUNDARAMOORTHI C., KALAIVANI M., SELVAM K. Production of lipase from Streptomyces griseus and evaluation of Bioparameters. International J. Chem. Tech. Res, 2 (3), 1380, 2010.

29. NISHA P., NAYANA M., ASOKAN A. Production of lipase from Micrococcus flavus and influence of bioparameters. IOSR Journal of Pharmacy and Biological Sciences, 9 (2), 67, 2014.

30. OLAJUYIGBE F.M., EHIOSUN K.L. Production of thermostable and organic solvent-tolerant alkaline protease from Bacillus coagulans PSB- 07 under different submerged fermentation conditions. African Journal of Biotechnology, 12 (21), 3341, 2013.

31. NISHA P., DAS A., SARITHA K.V. Production of Cellulase from Micrococcus spand effect of growth parameters. International Journal of Pharma Research and Health Sciences, 2 (3), 236, 2014. 